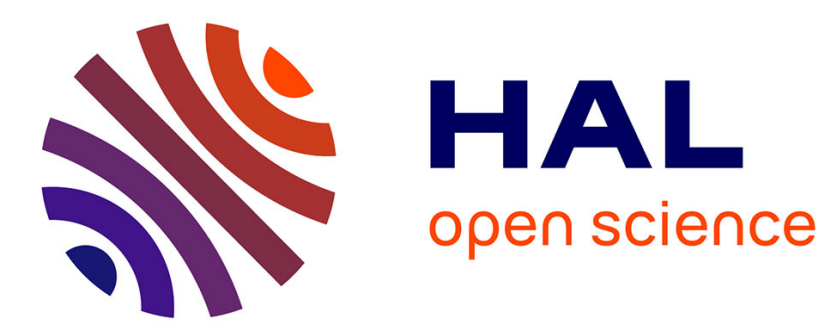

\title{
The effect of the calcium source, level and the particle size on calcium retention, eggshell quality and the overall calcium requirement in laying hens
}

\author{
Martina Lichovnikova
}

\section{- To cite this version:}

Martina Lichovnikova. The effect of the calcium source, level and the particle size on calcium retention, eggshell quality and the overall calcium requirement in laying hens. British Poultry Science, 2007, 48 (01), pp.71-75. 10.1080/00071660601148203 . hal-00545309

\author{
HAL Id: hal-00545309 \\ https://hal.science/hal-00545309
}

Submitted on 10 Dec 2010

HAL is a multi-disciplinary open access archive for the deposit and dissemination of scientific research documents, whether they are published or not. The documents may come from teaching and research institutions in France or abroad, or from public or private research centers.
L'archive ouverte pluridisciplinaire HAL, est destinée au dépôt et à la diffusion de documents scientifiques de niveau recherche, publiés ou non, émanant des établissements d'enseignement et de recherche français ou étrangers, des laboratoires publics ou privés. 


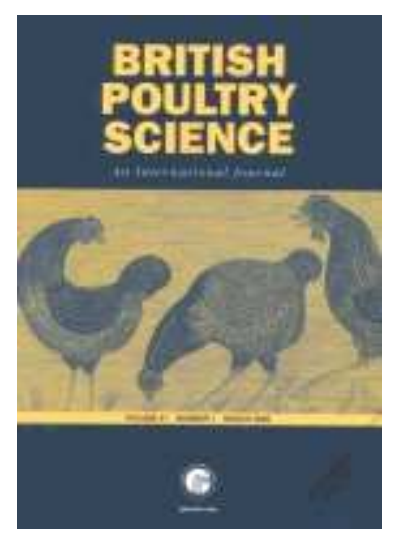

The effect of the calcium source, level and the particle size on calcium retention, eggshell quality and the overall calcium requirement in laying hens

\begin{tabular}{|r|l|}
\hline Journal: & British Poultry Science \\
\hline Manuscript ID: & CBPS-2006-246.R1 \\
\hline Manuscript Type: & Original Manuscript \\
\hline Date Submitted by the \\
Author: & 20-Oct-2006 \\
\hline Complete List of Authors: & $\begin{array}{l}\text { Lichovnikova, Martina; Mendel University of Agriculture and } \\
\text { Forestry }\end{array}$ \\
\hline Keywords: & Digestion, Egg shell, Laying hens \\
\hline
\end{tabular}

\section{今) ScholarONE \\ Manuscript Central}




\section{CBPS_2006_246}

edited M G MacLeod, November 2006

\section{2}

6 The effect of dietary calcium source, concentration and particle size

7 on calcium retention, eggshell quality and overall calcium

8 requirement in laying hens

9

10 M. LICHNIKOVA

11

12 Department of Animal Breeding, Mendel University of Agriculture and Forestry in

13 Brno, Zemedelska 1, 61300 Brno, Czech Republic

14

23 Telephone: ++420 545133229

24 Email: $\quad \underline{\text { lichov@mendelu.cz }}$

\section{RUNNING TITLE: CALCIUM SOURCE AND SHELL QUALITY}

16 
25 Abstract 1. Four different sources of calcium in isonitrogenous and isoenergeric

26 diets were fed to laying hens for two weeks when they were 56 and 57 weeks old.

27 The calcium source blends were as follows: $29 \%$ fine limestone (LF) $+71 \%$ large

28 limestone (LG), 32\% fine limestone (LF) + 68\% eggshell, 32\% fine limestone (LF) +

$2968 \%$ oyster shell, $50 \%$ fine limestone $+50 \%$ large limestone (LG). The contents of

30 these blends of calcium in the diets were as follows: $103.3 \mathrm{~g} / \mathrm{kg}, 93.3 \mathrm{~g} / \mathrm{kg}, 93.3 \mathrm{~g} / \mathrm{kg}$

31 and $93.3 \mathrm{~g} / \mathrm{kg}$ respectively.

32 2. The coefficients of calcium retention were significantly higher in 50:50 LF:LG

33 (0.578) and 32:68 LF:eggshell (0.576). The midnight feeding significantly improved

34 the coefficient of calcium retention in all mixtures except 50:50 LF:LG.

35 3. In the mixture 29:71 LF:LG and 32:68 LF:oyster shell, there was significantly

36 greater eggshell quality, eggshell weight, eggshell thickness and eggshell strength.

37 Midnight feeding had no significant effect on eggshell quality.

38 4. In the ration with oyster shells, $96.5 \%$ of the retained calcium was deposited in the

39 eggshell, but in ration 32:68 LF:eggshells and 50:50 LF:LG the utilisation was only

$40 \quad 73.9 \%$ and $78.6 \%$ respectively.

41 5. To ensure good quality eggshells in the last third of production, the

42 recommendation for calcium is $4.1 \mathrm{~g} / \mathrm{kg}(900 \mathrm{~g} / \mathrm{kg}$ dry matter, feed intake $110 \mathrm{~g} / \mathrm{d})$.

43 As a source of calcium in this stage of production, a feed mixture containing two-

44 thirds large particles should be used (limestone grit or oyster shell).

\section{INTRODUCTION}

46 The quality of the eggshells has a major influence on the economics of egg

47 production. Damaged or broken shells account for $6-8 \%$ of all the eggs laid (Bain,

48 1997) and the highest incidence of cracked eggs occurs mainly in the last third of the

49 laying period (after 53 weeks of age). The source and particle size of mineral 
50 nutrients, mainly calcium, play an important role in maintaining eggshell quality. It

51 is known that hens given ground limestone as a single source of calcium had lower

52 eggshell quality than hens fed blends of particulate and ground limestone (Guinotte

53 and Nys, 1991; Richter et al., 1999; Pavlovski et al., 2003; Koreleski and

54 Swiatkiewicz, 2004).

55 Rao et al. (1992) reported that limestone solubility in laying hens improves if 56 retention time is prolonged in the gizzard, which means feeding a minimum particle

57 size of $1.0 \mathrm{~mm}$. A minimum particle size less than $1.0 \mathrm{~mm}$ did not sustain retention 58 in the gizzard. Scheideler (1998) reported significantly greater specific gravity $59(P<0.05)$ of the eggs from the hens on the diets, which included large particle size 60 calcium (fine and large limestone 50:50 or 75:25 limestone:oyster shell in the diets) 61 compared with hens fed with diets containing $100 \%$ fine limestone or $100 \%$ ground 62 eggshell. Scheideler (2004), on the basis of her results, recommends that laying hens 63 be fed at least $25 \%$ of their calcium from a large particle calcium source. Also, 64 Ahmad and Balander (2003) reported higher egg specific gravity with the partial 65 replacement of limestone (50\%) with oyster shell as the calcium source. However, 66 not enough data exists at this time to justify increasing the large particle portion to 67 more than $50 \%$ of the ration. Also the requirement of calcium may not be the same, 68 as reported in earlier studies or NRC (1994), to meet the demand for relatively high 69 production in the last third of the laying period. The aim of the present study was to 70 evaluate the effects of a higher proportion of the large particle calcium (taken from 71 different sources) and higher calcium concentration on the calcium retention and the 72 eggshell quality in the last third of the laying period. 
74 A total of 24 laying hens were divided into 4 groups and they were kept in individual

75 balance cages. They were all fed on the same basic diet (corn $407 \mathrm{~g} / \mathrm{kg} \%$, wheat 340

$76 \mathrm{~g} / \mathrm{kg}$, soybean meal $138 \mathrm{~g} / \mathrm{kg}$ ). The 4 diets, however, varied in the source of calcium

77 as follows: $29 \%$ fine limestone (LF) + 71\% large limestone (LG: $1-2 \mathrm{~mm}$ x $1 \mathrm{~mm}$ ),

$7832 \%$ fine limestone and $68 \%$ eggshell $(2-5 \mathrm{~mm} \times 0.4 \mathrm{~mm}$ in the first digestion trial

79 and $1-2 \mathrm{~mm} \times 0.4 \mathrm{~mm} \times 0.8 \mathrm{~mm}$ in the second digestion trial), $32 \%$ fine limestone

80 and 68\% oyster shell (2 - 5 mm, Oyta Oystershells no. 1), 50\% fine limestone and

$8150 \%$ large limestone $(1-2 \mathrm{~mm})$. The contents of these sources of calcium in the diets

82 were as follows: $103.3 \mathrm{~g} / \mathrm{kg}, 93.3 \mathrm{~g} / \mathrm{kg}, 93.3 \mathrm{~g} / \mathrm{kg}$ and $93.3 \mathrm{~g} / \mathrm{kg}$ respectively;

83 consequently, the content of calcium was higher in the diet 29:68 LF:LG. The fine

84 limestone and the large limestone were from the same source. The compositions of

85 the diets are shown in Table 1. After a 5-d adjustment period, when the hens were

86 fed ad libitum, two digestion trials were done. Each digestion trial took $5 \mathrm{~d}$ and

87 between digestion trials there was a 2-d pause. In both trials the same hens received

88 the same diets. The results in each group were calculated as average of 12 samples (2

$89 \mathrm{x}$ 6). The hens were 56 and 57 weeks of age. Light was provided for $16 \mathrm{~h}$ per $\mathrm{d}$ from

$900400 \mathrm{~h}$ to $2000 \mathrm{~h}$. During the first digestion trial the hens were given $120 \mathrm{~g}$ of the

91 mixtures at $0830 \mathrm{~h}$. In the second digestion trial, a midnight feeding was added and

92 the hens were fed $90 \mathrm{~g}$ of the mixtures during the light period and $30 \mathrm{~g}$ during the

93 dark period. At the end of each digestion trial the remainder of the diets in the

94 feeders were weighed and average daily food intake was calculated for each hen.

95 During the dark period the light was turned on for $1 \mathrm{~h}$ from $2400 \mathrm{~h}$ to $0100 \mathrm{~h}$. Water

96 was provided ad libitum throughout the day. Droppings were collected every $24 \mathrm{~h}$

97 and dried at $65{ }^{\circ} \mathrm{C}$ each day after collection. The retention of calcium, energy,

98 nitrogen, ash, phosphorus and fat were estimated using the indicator method. 
99 Insoluble ash in $3 \mathrm{M} \mathrm{HCl}$ was used as an indicator. The content of nitrogen was

100 determined according to Kjeldahl. The content of fat was determined according to

101 Soxhlet. Ash was determined after combustion at $550{ }^{\circ} \mathrm{C}$. The content of calcium and

102 phosphorus were determined by spectrophotometry. The energy was determined in

103 an automatic bomb calorimeter PARR 1281 (Parr Instrument Company, Illinois,

104 USA). An acid correction was not done. All the eggs were collected and weighed.

105 The strength of the eggshells (N) was measured manually by destructive methods.

106 Eggs were compressed between two parallel plates by a steadily increasing load until

107 failure resulted. The force was recorded throughout each test and the strength of the

108 eggshell was given in terms of the force at failure. The force was measured vertically

109 to the axis. Also the thickness (the average of both ends and at the middle) of

110 eggshell was evaluated and dry eggshells were weighed.

Table 1 near here

111 On the basis of the weight of the eggshells, the calcium content in the

112 eggshells and the calcium retention, the proportions of retained calcium deposited in

113 the eggshells were determined in each group. The following equations were used:

$114 \mathrm{Ca}_{\mathrm{p}}=100 * \mathrm{Ca}_{\mathrm{a}} / \mathrm{Ca}_{\mathrm{r}}$

$115 \mathrm{Ca}_{\mathrm{p}}=$ proportion of retained $\mathrm{Ca}$ deposited into the eggshells (\%)

$116 \mathrm{Ca}_{\mathrm{a}}=$ amount of calcium deposited to the eggshells $(\mathrm{g} / \mathrm{hen} / \mathrm{d})$

$117 \quad \mathrm{Ca}_{\mathrm{a}}=\mathrm{Wt}_{\mathrm{e}} \times \mathrm{Ca}_{\mathrm{e}} / 100$

$118 \quad \mathrm{Wt}_{\mathrm{e}}=$ weight of dry eggshells $(\mathrm{g} / \mathrm{hen} . \mathrm{d})$

$119 \quad \mathrm{Ca}_{\mathrm{e}}=$ calcium content in the eggshells $(\%)$

$120 \quad \mathrm{Ca}_{\mathrm{r}}=$ calcium retention $(\mathrm{g} / \mathrm{hen} . \mathrm{d})$

$121 \quad \mathrm{Ca}_{\mathrm{r}}=\mathrm{Ca}_{\mathrm{i}} \times \mathrm{Ca}_{\mathrm{c}}$

$122 \quad \mathrm{Ca}_{\mathrm{i}}=$ calcium intake $(\mathrm{g} / \mathrm{hen} . \mathrm{d})$

$123 \quad \mathrm{Ca}_{\mathrm{c}}=$ coefficient of calcium retention 
Data were analysed throughout by one-way analysis of variance (ANOVA)

125 using the software package Unistat 5.1 (UNISTAT Ltd, England). Tukey-HSD

126 (eggshell quality), and Least Significant Difference (the coefficients of nutrient

127 retention) were used as the post hoc test for all possible pair-wise comparisons within

128 groups.

129 The in vitro solubility of the limestone used in the study was determined by

130 the method described by Zhang and Coon (1997). A 2.0 g limestone sample was

131 poured into a $400 \mathrm{ml}$ beaker containing $200 \mathrm{ml}$ of $0.2 \mathrm{~N} \mathrm{HCl}$ solution that was

132 warmed at $42{ }^{\circ} \mathrm{C}$ until the temperature of the solution became constant in a water

133 bath oscillation at $80 \mathrm{~Hz}$. After allowing $10 \mathrm{~min}$ for reaction, the undissolved

134 limestone was filtered onto a preweighed filter paper and weighted after draying in a

$13560{ }^{\circ} \mathrm{C}$ oven for $20 \mathrm{~h}$. The in vitro solubility of limestone vas expressed as the

136 percentage weight loss.

\section{RESULTS AND DISCUSSION}

138 The coefficients of the retention of the dry matter, fat, energy, calcium, nitrogen, ash

139 and phosphorus are shown in Table 2. The coefficients of the calcium retention were

140 significantly higher $(P=0.0271)$ in 50:50 LF:LG and LF:Eggshell in comparison with

141 29:71 LF:LG and LF:Oystershell. Also, Scheideler (1998) found that the highest

142 retention of calcium was from eggshells. The midnight feeding significantly

143 improved the retention of calcium $(P<0.01)$ in all of the groups except 50:50 LF:LG

144 (Table 4). The highest retention of calcium and the highest retention of all others

145 nutrients (energy, nitrogen, ash and phosphorus) were found in the rations with

146 eggshells.

Tables 2,3,4 near here

147 The weight of the eggs and the quality of the eggshells is shown in Table 3.

148 The weight of the eggs was significantly lower $(P=0.0422)$ in the 29:71 LF:LG. In 
149 this group the amount of calcium was the highest. The retention of energy was 150 significantly lower $(P=<0.05)$. However, Rao et al. (2003), Chandramoni et al. 151 (1998), and Keshavarz and Nakajima (1993) did not find any indications of calcium 152 contents greater than $32.5 \mathrm{~g} / \mathrm{kg}$ (max. $55.0 \mathrm{Ca} \mathrm{g} / \mathrm{kg}$ ) of the egg weight. The midnight

153 feeding significantly increased the weight of the eggs $(P<0.05)$ except in the 50:50 154 LF:LG group (Table 4). The midnight feeding did not have a significant effect on the 155 eggshell quality. The eggshell weight $(P<0.05)$, thickness $(P<0.001)$ and strength $156(P=0.001)$ were significantly higher in the group with oyster shell and 29:71 LF:LG 157 in comparison with the diets containing eggshell and 50:50 LF:LG. The same 158 improvement of eggshell strength was reported by Richter et al. (1999) when the 159 hens were given limestone with a particle size of $0.5-2.0 \mathrm{~mm}$, or a mixture of one160 third finely ground limestone and two-thirds oyster shell. The beneficial effects of 161 oyster shell on eggshell quality were consistent with the reports of Keshavarz and 162 Nakajima (1993). Although also in the group 32:68 LF:eggshell the greater the 163 amount of large particles the worse was the quality of the eggshell (eggshell weight, 164 eggshell weight ratio and eggshell thickness). This may have been due to the low 165 solubility of the eggshells. The in vitro solubility was as follows: fine limestone $16685.0 \%$, eggshells $14.0 \%$, oyster shell $44.0 \%$ and large limestone $49.5 \%$. Cheng and 167 Coon (1990) reported that the eggshell quality (and bone status) were more closely 168 related with limestone in vitro solubility than particle size. The researchers indicated 169 a potential difference in calcium retention for layers when two calcium sources of the 170 same particle size with different in vitro solubility were compared. On the other 171 hand, Rao and Roland (1990) reported that in vivo calcium solubilisation in laying 172 hens, for the particle size tested, was not influenced by in vitro limestone solubility. 
The source and the particle size of the calcium probably have a greater effect

174 on eggshell quality than does the calcium level. Although in the 29:71 LF:LG diet

175 the content of calcium was about $12 \%$ higher than in the 32:68 LF:oyster shell diet,

176 the quality of the eggshell was not improved. There was no significant difference in

177 eggshell strength, thickness, weight ratio or eggshell weight between these groups.

178 Neither Chandramoni et al. (1998) who used calcium concentrations of 32.5, 36.0

179 and $39.0 \mathrm{~g} / \mathrm{kg}$ nor Rao et al. (2003), who used 32.5, 35.0, 37.5, 40.0, 42.5 and 45.0

$180 \mathrm{~g} / \mathrm{kg}$, observed any improvement in the eggshell quality (eggshell weight, eggshell

181 weight per unit surface area and eggshell weight, and eggshell thickness

182 respectively). However, Chandramoni et al. (1998) used limestone powder and bone

183 meal. Rao et al. (2003) used oyster shell (powder and grit 1 - $2 \mathrm{~mm}$ ) but the weights

184 of the eggs in their experiments were almost $10 \mathrm{~g}$ lighter than the eggs in this

185 experiment were, and consequently the requirement of calcium was lower.

186 Contrary to Clunies et al. (1992), there was no significant difference in the

187 total retention of calcium between the groups, which allowed higher and lower

188 eggshell quality (thickness). Also Keshavarz and Nakajima (1993) did not find any

189 significant difference in the total retention of calcium among concentrations of 35.0 -

$19055.0 \mathrm{~g} / \mathrm{kg}$ in the diets. Probably the ability to utilise the calcium from the retained

191 calcium for eggshell formation plays an important role. The utilisation of calcium for

192 the formation of the eggshell was calculated and shown in Table 3. It was calculated

193 on the basis of calcium retention, eggshell production (Figure 1) and the calcium

194 content of the eggshells. The daily intake of calcium and the content of calcium in

195 the eggshells are shown in Table 3. In the group of hens given oyster shells, $96.5 \%$

196 of the retained calcium was deposited in the eggshells. In the groups given eggshells

197 and 50:50 LF:LG the utilisation was only 73.9 and $78.6 \%$ respectively, although the 
198 coefficients of calcium retention were significantly higher $(P<0.05)$ in these groups.

199 There was no difference in the daily eggshell production (g) among the groups

200 (Figure 1). This was probably due to the fact that the hens digest the calcium from

201 the large particle oyster shell $(2-5 \mathrm{~mm})$ slowly but constantly, and it is utilised

202 immediately for eggshell formation.

Figure 1 near here

203 Conclusions

204 Two thirds of the calcium source should be fed in the form of large particles

205 (limestone grit or oyster shell) in the last third of the laying period to ensure good

206 eggshell quality. Leeson et al. (1993) indicated that $3.4 \mathrm{~g}$ calcium/d is enough for

207 brown-egg layers because they did not observe any effect of higher levels of calcium

208 on eggshell deformation in these hens, but they used only limestone as a source of

209 calcium in all of the rations. On the basis of the present study, eggshell quality can be

210 improved by using suitable sources and particle sizes of calcium. Higher retention or

211 concentration of calcium does not, in itself, mean better eggshell quality.

\section{ACKNOWLEDGEMENTS}

213 The author thanks Judy McPherson for the language correction and Assistant

214 Professor Stanislav Kracmar, Dr.Sc. for the measurements of energy in the samples.

215 The results were obtained with financial support of project 42/2005 IGA of Mendel

216 University of Agriculture and Forestry in Brno.

\section{REFERENCES}

218 AHMAD, H.A. \& BALANDER, R.J. (2003) Alternative Feeding Regimen of

219 Calcium Source and Phosphorus Level for Better Eggshell Quality in

220 Commercial Layers. Journal of Applied Poultry Research 12: 509-514.

221 BAIN, M.M. (1997) A reinterpretation of eggshell strength. In SOLOMON, S.E. Egg

222 and Eggshell Quality. London: Manson Publishing Ltd. 131-142. 
223 CHANDRAMONI, JADHAO, S.B. \& SINHA, R.P. (1998) Effect of Dietary

224 Calcium and Phosphorus Concentrations on Retention of these Nutrients by 225 Caged Layers. British Poultry Science 39: 544-548.

226 CHENG, T.K. \& COON, C.N. (1990) Effect of Ca Source, Particle Size, Limestone 227 Solubility in vitro, and Ca Intake Level on Layer Bone Status and Performance. $228 \quad$ Poultry Science 69: 2228-2230.

229 CLUNIES, M., PARKS, D. \& LEESON, S. (1992) Calcium and Phosphorus 230 Metabolism and Eggshell Thickness in Laying Hens Producing Thick or Thin $231 \quad$ Shells. Poultry Science 71: 490-498.

232 GUINOTTE, F. \& NYS, Y. (1991) Effects of Particle Size and Origin of Calcium 233 Sources on Eggshell Quality and Bone Mineralization in Egg Laying Hens. $234 \quad$ Poultry Science 70: 583-592.

235 KESHAVARZ, K. \& NAKAJIMA, S. (1993) Re-Evaluation of Calcium and 236 Phosphorus REquirements of Laying Hens for Optimum Performance and $237 \quad$ Eggshell Quality. Poultry Science 72: 144-153.

238 KORELESKI, J. \& SWIATKIEWICZ, S. (2004) Calcium from Limestone Meal and 239 Grit in Laying Hen Diets - Effect on Performance, Eggshell and Bone Quality. $240 \quad$ Journal of Animal and Feed Sciences 13: 635-645.

241 LEESON, S., SUMMERS, D. \& CASTON, L. (1993) Response of Brown-Egg 242 Strain Laywrs to Dietary Calcium or Phosphorus. Poultry Science 72: 1510-1514. 243 PAVlovski, Z., VITOROVIC, D., LUKIC, M. \& SPASOJEVIC, I. (2003) 244 Improving Eggshell Quality by Replacement of Pulverised Limestone by 245 Granular Limestone in the Hen Diet. Acta Veterinaria-Bograd 53: 35-40.

246 RAO, K.S. \& ROLAND, D.A. (1990) In Vivo Limestone Solubilization in 247 Commercial Leghorns - Role of Dietary Calcium Level, Limestone Particle Size, 
In Vitro Limestone solubility Rate, and the Calcium Status of the Hen. Poultry Science 69: 2170-2176.

RAO, K.S., ROLAND, D.A., ADAMS, J.L. \& DURBORAW, W.M. (1992)

251 Improved Limestone Retention in the Gizzard of Commercial Leghorn Hens. 252 Journal of Applied Poultry Research 1: 6-10.

253 RAO, S.V.R., PNADA, A.K., RAJU, M.V.L.N., SUNDER, G.S. \& PRAHARAJ, 254 N.K. (2003) Requirement of Calcium for Commercial Broilers and White 255 Leghorn Layers at Low Dietary Phosphorus Levels. Animal Feed Science and 256 Technology 106: 199-208.

257 RICHTER, G., KIESSLING, G., OCHRIMENKO, W.I. \& LUDKE, H. (1999) 258 Influence of Particle Size and Calcium Source on Limestone Solubility in vitro, 259 Performance and Eggshell Quality in Laying Hens. Archiv für Geflügelkunde 63: $260 \quad 208-213$.

261 SCHEIDELER, S.E. (1998) Eggshell calcium effects on egg quality and Ca 262 digestibility in first- or third-cycle laying hens. Journal of Applied Poultry $263 \quad$ Research 7: 69-74.

264 SCHEIDELER, S.E. (2004) Calcium Source, Practicle Size and Calcium Level for 265 Laying Hens. In Proceedings of the Midwest Poultry Federation Convention. St. 266 Paul, MN, MN: Midwest Poultry Federation.

267 ZANG, B. \& COON C.N. (1997) The Relationship of Calcium Intake, Source, Size, 268 Solubility In Vitro and In Vivo, and Gizzard Limestone Retention in Laying 269 Hens. Poultry Science 76: 1702-1706. 
Table 1. The composition of the diets

\begin{tabular}{|c|c|c|c|c|}
\hline Composition $(\mathrm{g} / \mathrm{kg})$ & 29:71 LF:LG & 32:68 LF:eggshell & 32:68 LF:oyster shell & 50:50 LF:LG \\
\hline Maize & & & & \\
\hline Wheat & & & & \\
\hline Soybean meal & & & & \\
\hline Monocalcium phosphate & & & & \\
\hline Methionine & & & & \\
\hline L-lysine & & & & \\
\hline Salt & & & & \\
\hline Premix & & & & \\
\hline Limestone Fine & 30 & 30 & 30 & 46.65 \\
\hline Lime Grit & $73.3 *$ & - & - & 46.65 \\
\hline Eggshells & - & 63.3 & - & - \\
\hline Oyster shells & - & - & 63.3 & - \\
\hline Calcium $(\mathrm{g} / \mathrm{kg})$ & 44.6 & 39.7 & 39.8 & 40.8 \\
\hline Total phosphorus (g/kg) & 5.7 & 5.2 & 5.4 & 5.2 \\
\hline
\end{tabular}

* The content of wheat was $330 \mathrm{~g} / \mathrm{kg}$ in this diet. 
Table 2. The coefficients of nutrient retention

\begin{tabular}{lccccc}
\hline & $\begin{array}{c}29: 71 \mathrm{LF}: \mathrm{LG} \\
\text { Mean } \pm \mathrm{SE}\end{array}$ & $\begin{array}{c}\text { 32:68 LF:eggshell } \\
\text { Mean } \pm \mathrm{SE}\end{array}$ & $\begin{array}{c}\text { 32:68 LF:oyster shell } \\
\text { Mean } \pm \mathrm{SE}\end{array}$ & $\begin{array}{c}\text { 50:50 LF:LG } \\
\text { Mean } \pm \text { SE }\end{array}$ & $\begin{array}{c}P \text {-values } \\
\text { Retention of nutrients }\end{array}$ \\
\hline Dry matter & $0.714 \pm 0.0139^{\mathrm{a}}$ & $0.784 \pm 0.0136^{\mathrm{b}}$ & $0.748 \pm 0.0173$ & $0.751 \pm 0.0121$ & $<0.05$ \\
Energy & $0.758 \pm 0.0135^{\mathrm{a}}$ & $0.818 \pm 0.0136^{\mathrm{b}}$ & $0.786 \pm 0.0168$ & $0.786 \pm 0.0123$ & $<0.05$ \\
Nitrogen & $0.367 \pm 0.0353^{\mathrm{a}}$ & $0.541 \pm 0.0290^{\mathrm{b}}$ & $0.465 \pm 0.0441$ & $0.455 \pm 0.0290$ & $<0.05$ \\
Ash & $0.488 \pm 0.0134^{\mathrm{b}}$ & $0.577 \pm 0.0134^{\mathrm{a}}$ & $0.518 \pm 0.0165^{\mathrm{b}}$ & $0.515 \pm 0.0131^{\mathrm{b}}$ & $<0.001$ \\
Calcium - Ca & $0.506 \pm 0.0142^{\mathrm{a}}$ & $0.576 \pm 0.0177^{\mathrm{b}}$ & $0.515 \pm 0.0334^{\mathrm{a}}$ & $0.578 \pm 0.0123^{\mathrm{b}}$ & $<0.05$ \\
Phosphorus & $0.219 \pm 0.0464^{\mathrm{a}}$ & $0.415 \pm 0.0420^{\mathrm{b}}$ & $0.353 \pm 0.0388^{\mathrm{b}}$ & $0.293 \pm 0.0484$ & $<0.05$ \\
Fat & $0.683 \pm 0.0247$ & $0.735 \pm 0.0231$ & $0.712 \pm 0.0271$ & $0.677 \pm 0.0217$ & $\mathrm{NS}$ \\
\hline
\end{tabular}

SE - standard error.

NS - non-significant.

${ }^{a, b, c}$ Values in a row not sharing a common superscript are significantly different at $\mathrm{P}<0.05$. 
Table 3. Eggshell quality and calcium requirements

\begin{tabular}{|c|c|c|c|c|c|}
\hline & $\begin{array}{l}\text { 29:71 LF:LG } \\
\text { Mean } \pm \text { SE }\end{array}$ & $\begin{array}{l}\text { 32:68 LF:Eggshell } \\
\text { Mean } \pm \mathrm{SE}\end{array}$ & $\begin{array}{l}\text { 32:68 LF:Oyster shell } \\
\quad \text { Mean } \pm \text { SE }\end{array}$ & $\begin{array}{l}\text { 50:50 LF:LG } \\
\text { Mean } \pm \text { SE }\end{array}$ & $P$-values \\
\hline Egg production (eggs) & 52 & 49 & 46 & 53 & - \\
\hline Food intake $(\mathrm{g} / \mathrm{d})$ & 109.3 & 108.5 & 104.9 & 109.3 & - \\
\hline Ca intake $-\mathbf{C} \mathbf{a}_{\mathbf{i}}(\mathrm{g} / \mathrm{d})$ & $4.9 \pm 0.24$ & $4.3 \pm 0.20$ & $4.2 \pm 0.30$ & $4.5 \pm 0.13$ & NS \\
\hline Weight of hens (kg) & $1.63 \pm 0.074$ & $1.66 \pm 0.057$ & $1.76 \pm 0.075$ & $1.65 \pm 0.091$ & NS \\
\hline Egg weight $(g)$ & $61.7 \pm 0.45^{\mathrm{a}}$ & $63.7 \pm 0.66^{\mathrm{b}}$ & $64.0 \pm 0.59^{b}$ & $63.9 \pm 0.78^{b}$ & $<0.05$ \\
\hline Eggshell weight (g) & $6.63 \pm 0.058^{b}$ & $6.24 \pm 0.086^{\mathrm{a}}$ & $6.69 \pm 0.110^{b}$ & $6.40 \pm 0.130$ & $<0.01$ \\
\hline Eggshell weight ratio (\%) & $10.8 \pm 0.087^{\mathrm{b}}$ & $9.81 \pm 0.108^{\mathrm{ac}}$ & $10.4 \pm 0.126^{\mathrm{bc}}$ & $10.0 \pm 0.154^{\mathrm{c}}$ & $<0.001$ \\
\hline Eggshell thickness (mm) & $0.432 \pm 0.0034^{\mathrm{b}}$ & $0.397 \pm 0.0045^{\mathrm{a}}$ & $0.428 \pm 0.0050^{\mathrm{b}}$ & $0.406 \pm 0.0067^{\mathrm{a}}$ & $<0.001$ \\
\hline Eggshell strength $(\mathrm{N})$ & $38.1 \pm 1.01^{\mathrm{b}}$ & $35.7 \pm 0.97$ & $39.1 \pm 1.14^{\mathrm{b}}$ & $32.6 \pm 1.65^{\mathrm{a}}$ & $<0.01$ \\
\hline Ca in eggshell $-\mathbf{C a}_{\mathbf{e}}(\mathrm{g} / \mathrm{kg})$ & $359.7 \pm 1.75$ & $359.1 \pm 1.30$ & $359.8 \pm 1.26$ & $359.4 \pm 1.26$ & NS \\
\hline Ca eggshell : Ca retention $-\mathbf{C a}_{\mathbf{p}}(\%)$ & $84.1 \pm 4.18$ & $73.9 \pm 8.04$ & $96.5 \pm 10.0$ & $78.6 \pm 3.97$ & NS \\
\hline
\end{tabular}

SE - standard error.

NS - non-significant.

${ }^{\mathrm{a}, \mathrm{b}, \mathrm{c}}$ Values in a row not sharing a common superscript are significantly different at $P<0.05$. 
Table 4. The effect of midnight feeding on the coefficients of calcium retention and egg weight

\begin{tabular}{lcccc}
\hline & $\begin{array}{c}29: 71 \mathrm{LF}: \mathrm{LG} \\
\text { Mean } \pm \mathrm{SE}\end{array}$ & $\begin{array}{c}32: 68 \mathrm{LF}: \text { Eggshell } \\
\text { Mean } \pm \mathrm{SE}\end{array}$ & $\begin{array}{c}\text { 32:68 LF:Oyster shell } \\
\text { Mean } \pm \text { SE }\end{array}$ & $\begin{array}{c}50: 50 \text { LF:LG } \\
\text { Mean } \pm \text { SE }\end{array}$ \\
\hline Retention of calcium & & & & \\
\hline Daily feeding & $0.471 \pm 0.0161$ & $0.525 \pm 0.0163$ & $0.418 \pm 0.0324$ & $0.564 \pm 0.0136$ \\
Midnight feeding & $0.540 \pm 0.0124$ & $0.628 \pm 0.0061$ & $0.613 \pm 0.0747$ & $0.591 \pm 0.0203$ \\
$P$-values & $<0.01$ & $<0.001$ & $<0.001$ & $\mathrm{NS}$ \\
\hline Weight of eggs & & & & $62.8 \pm 1.02$ \\
\hline Daily feeding & $60.8 \pm 0.62$ & $61.7 \pm 0.81$ & $62.3 \pm 0.77$ & $64.5 \pm 1.12$ \\
Midnight feeding & $62.6 \pm 0.60$ & $65.4 \pm 0.83$ & $65.8 \pm 0.82$ & $\mathrm{NS}$ \\
$P$-values & $<0.05$ & $<0.01$ & $<0.01$ & \\
\hline
\end{tabular}

SE - standard error.

NS - non-significant. 


1
2
3
4
5
6
7
8
9
10
11
12
13
14
15
16
17
18
19
20
21
22
23
24
25
26
27
28
29
30
31
32
33
34
35
36
37
38
39
40
41
42
43
44
45
46
47
48
49
50
51
52
53
54
55
56
57
58
59
60

Figure 1. Daily eggshell production (g/hen).

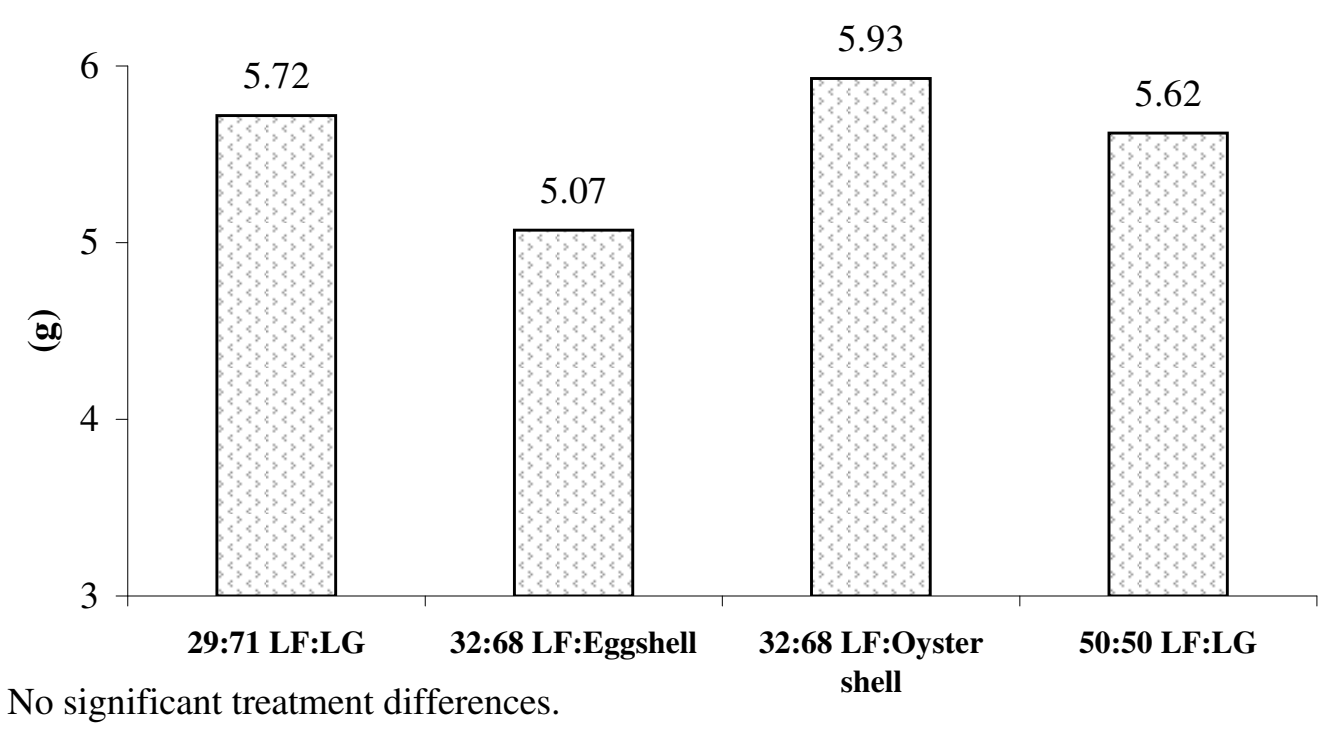

No significant treatment differences. 